\title{
THE FUTURE FACULTY OF ARCHITECTURE AND EKISTICS (FAE)
}

\author{
SURIATINI ISMAIL* \\ AHMAD RASDAN ISMAIL** \\ KHAIRUL AZHAR MAT DAUD*** \\ NIK ZULKARNAEN KHIDZIR ${ }^{* * * *}$ \\ ABU HASSAN HASBULLAH***** \\ ABDUL AZIZ SHUAIB****** \\ NUZUL HAQIMI MUHAMMAD******* \\ ROSDI ABD.RAHMAN ${ }^{* * * * * * * *}$
}

\begin{abstract}
Abstrak
Karya ini menggariskan asas-asas bagi usaha pembentukan Fakulti Seni Bina dan Ekistik (FAE) di Universiti Malaysia Kelantan (UMK). Usaha untuk membentuk sebuah fakulti baru ini menyatakan komitmen UMK dalam melaksanakan pelan strategik Universiti untuk terus membangun melalui Fakulti Teknologi Kreatif dan Warisan (FTKW). Fakulti baru ini akan menjadi fakulti pertama di Malaysia yang menggunakan istilah "Ekistik" pada namanya. la dijelmakan bersama hasrat untuk mendepani cabaran futurism kreatif. Dua bidang utama di bawah naungan FAE ialah Alam Bina (BE) dan Pengurusan Alam Bina (BEM). Ini akan menjadi tonggak utama program-program akademik dan aktiviti penyelidikan di FAE. Penekanan kepada kesarjanaan pengajaran akan membawa FAE ke arah fakulti penyelidikan berteraskan warisan, teknologi kreatif dan keusahawanan yang digembeling bersama ntuk menyokong bidang teras iaitu seni bina dan ekistik.
\end{abstract}

Katakunci: Senibina, Ekistik, Masa Depan, Kreatif, Teknologi

\footnotetext{
${ }^{*}$ PhD, Pensyarah dan Penyelaras Program Seni Bina \& Ekistik, Fakulti Teknologi Kreatif \& Warisan, Universiti Malaysia Kelantan (UMK).

${ }^{* *}$ PhD, Profesor Madya dan Timbalan Dekan di Fakulti Teknologi Kreatif \& Warisan, Universiti Malaysia Kelantan (UMK).

*** PhD dan Timbalan Dekan di Fakulti Teknologi Kreatif \& Warisan, Universiti Malaysia Kelantan (UMK).

**** PhD dan Timbalan Dekan di Fakulti Teknologi Kreatif \& Warisan, Universiti Malaysia Kelantan (UMK).

***** Felo Utama Fakulti Teknologi Kreatif \& Warisan, Universiti Malaysia Kelantan (UMK).

****** PhD dan Profesor Madya di Fakulti Teknologi Kreatif \& Warisan, Universiti Malaysia Kelantan (UMK).

******* Pensyarah di Fakulti Teknologi Kreatif \& Warisan, Universiti Malaysia Kelantan (UMK).

******** Profesor di Fakulti Teknologi kreatif \& Warisan, Universiti Malaysia Kelantan (UMK)
} 


\begin{abstract}
This paper outlines the basis of formation for the future Faculty of Architecture and Ekistics (FAE) at Universiti Malaysia Kelantan (UMK). Efforts put towards the establishment of the new faculty manifest the commitment by UMK to pursue its strategic plan to continue developing further through its current Faculty of Creative Technology and Heritage (FTKW). The new faculty will be the first in Malaysia to use the term "Ekistics" in its name. This will come together with the aspiration to address creative futurism. Two main fields under the umbrella of FAE will be Built Environment (BE) and Built Environment Management (BEM). These will serve as the main pillars of academic programmes and research activities in FAE. By emphasising on the scholarship of teaching, FAE will move towards a research focus faculty with heritage, entrepreneurial and technology being blended together to support its main areas which are architecture and ekistics.
\end{abstract}

Keywords: Architecture, Ekistics, Futurism, Creative, Technology

\footnotetext{
* PhD, Pensyarah dan Ketua Program Seni Bina \& Ekistik, Fakulti Teknologi Kreatif \& Warisan, Universiti Malaysia Kelantan (UMK).

${ }^{* *}$ PhD, Profesor Madya dan Timbalan Dekan di Fakulti Teknologi Kreatif \& Warisan, Universiti Malaysia Kelantan (UMK).

*** PhD dan Timbalan Dekan di Fakulti Teknologi Kreatif \& Warisan, Universiti Malaysia Kelantan (UMK).

**** PhD dan Timbalan Dekan di Fakulti Teknologi Kreatif \& Warisan, Universiti Malaysia Kelantan (UMK).

***** PhD, Profesor dan Dekan di Fakulti Teknologi Kreatif \& Warisan, Universiti Malaysia Kelantan (UMK).

****** PhD dan Profesor Madya di Fakulti Teknologi Kreatif \& Warisan, Universiti Malaysia Kelantan (UMK).

******* Pensyarah di Fakulti Teknologi Kreatif \& Warisan, Universiti Malaysia Kelantan (UMK).

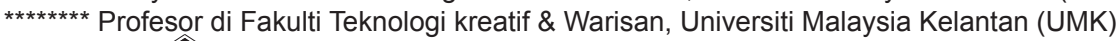




\subsection{Introduction}

The existing Faculty of Creative Technology and Heritage (FTKW) of Universiti Malaysia Kelantan (UMK) is committed in pursuing the University's strategic plan for a further development of its academic programmes and research agenda. It is taking its stride to expand the current teaching and learning platform at UMK by delivering the responsibility to form a new faculty named Faculty of Architecture and Ekistics (FAE). Efforts towards the formation of FAE are concerted under the FTKW strategic plan.

This paper outlines the basis of formation for the new faculty. It presents the main structure of implementation by highlighting how FAE fits into the multidisciplinary approach taken by FTKW in delivering its teaching and learning agenda. The paper is structured as follows: Section 2 introduces the two important terms that form the name of the new faculty. Section 3 outlines the aspiration of the current FTKW which is to be realised through the formation of the new faculty. Section 4 outlines the agenda that has been set up for the new faculty. Lastly, Section 5 concludes the paper.

\subsection{Architecture and Ekistics}

\subsection{Architecture}

Steven Holl (2013) describes the term"Architecture" in four words namely abstract, use, space and Idea. According to him, while artists work from the real to the abstract, architects must work from the abstract to the real. His analogy is that, while art may legitimize itself as an object or an event, architecture dissolves into a blur of buildings. He purports that "Architecture" that works under the constraints of engineering safety, function, climate responsibility and economy sometimes transcends to inspire people with ideas in space and light— qualities achieved in the abstract. From the perspective of "use", he describes that some artists qualify the difference between architecture and art as "use" versus "lack of use." A "function" of architecture is to inspire with a construction of luminous spatial energy. Its highest "use" is to deeply move people. Space is encountered by the body moving through space; architecture's volumes, connected in a path of overlapping perspectives. Architecture is the art of space where interior and exterior converge. It draws human from one location to the next. A work of architecture has an idea, which is an organic link between concept and form. This idea is a hidden thread connecting disparate parts with exact intention. Wikipedia (2014) proposes that "Architecture" has to do with planning, designing and constructing form, space and ambience to reflect functional, technical, social, environmental and aesthetic considerations. It requires the creative manipulation and coordination of materials and technology, and of light and shadow. Often, conflicting requirements must be resolved. The practise of Architecture also encompasses the pragmatic aspects of realizing buildings and structures, including scheduling, cost estimation and construction administration. Documentation produced by architects, typically drawings, plans and technical specifications, defines the structure and/or behavior of a building or other kind of system that is to be or has been constructed. Architecture forms part of "Ekistics". 


\subsection{Ekistics}

The following texts describe the term "Ekistics" based on Wikipedia (2014). The term Ekistics (coined by Konstantinos Apostolos Doxiadis in 1942) applies to the science of human settlements. It includes regional, city, community planning and dwelling design. It involves the study of all kinds of human settlements, with a view to geography and ecology — the physical environment — and human psychology and anthropology, and cultural, political, and occasionally aesthetics. As a scientific mode of study it is currently found to rely on statistics and description, organized in five ekistic elements: nature, anthropos, society, shells, and networks. It is generally a more scientific field than urban planning, and has considerable overlap with some of the less restrained fields of architectural theory. Doxiadis believed that the conclusion from biological and social experience was clear: to avoid chaos we must organize our system of life from Anthropos (individual) to Ecumenopolis (global city) in hierarchical levels, represented by human settlements. So he articulated a general hierarchical scale with fifteen levels of Ekistic Units as follows:

Names of Units and Population Scale (final version, from C.A.Doxiadis' last book, ACTION for Human Settlements, p. 186, Athens Center of Ekistics, 1976). Note: The population figures below are for Doxiadis' ideal future ekistic units for the year 2100 at which time he estimated (in 1968) that Earth would achieve zero population growth at a population of $50,000,000,000$ with human civilization being powered by fusion energy.

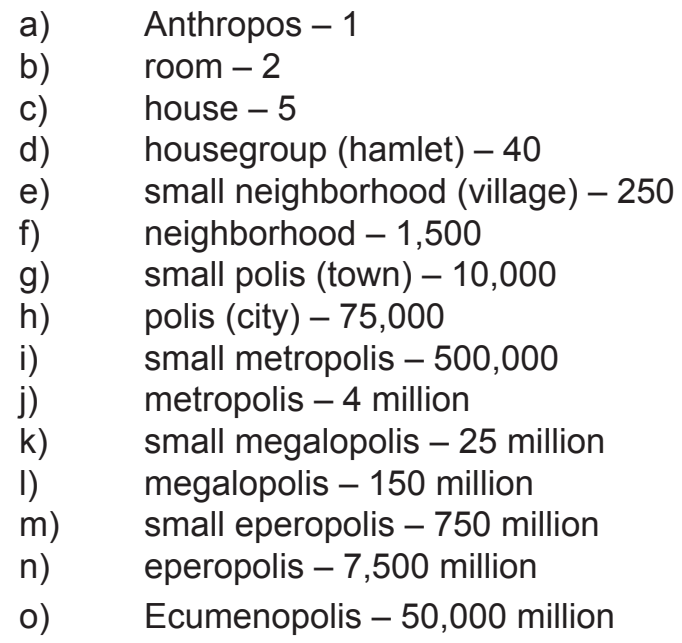




\subsection{The aspiration of FTKW}

Faculty of Creative Technology and Heritage (FTKW) is one of the earliest faculty formed together with Universiti Malaysia Kelantan (UMK). The establishment of this faculty is in line with the 9th Malaysia Plan which gives priority to the development of creative industries through.Dasar Industri Kreatif Negara (DIKN) covering media arts industry, the art digital technology, architecture, design, fine arts, music and performing arts, philosophy and arts and cultural heritage as well as the community (Abu Hassan, 2013).

FTKW in philosophy, mission and vision has put Heritage, Creative Futures; and Entrepreneurship as its core. This makes FTKW the only institution that offers these fields of study in a blended way, nationally and internationally. The teaching and learning agenda at FTKW is very much influenced by its tag line of "The past is where we share, the future is where we belong". As such it takes all the efforts to meet future demand of the society by carrying the inherited cultural values along the entrepreneurial approach. This has made a multidisciplinary approach the most appropriate for FTKW to develop its teaching and learning platform effectively. In realising this aspiration, FTKW has formed its research sub-clusters to include creative technology, cyberology and ekistics.

Figure 1 exhibits the newly formed research sub-clusters in FTKW. FAE forms part of the structure to fit the multidisciplinary research agenda of UMK.

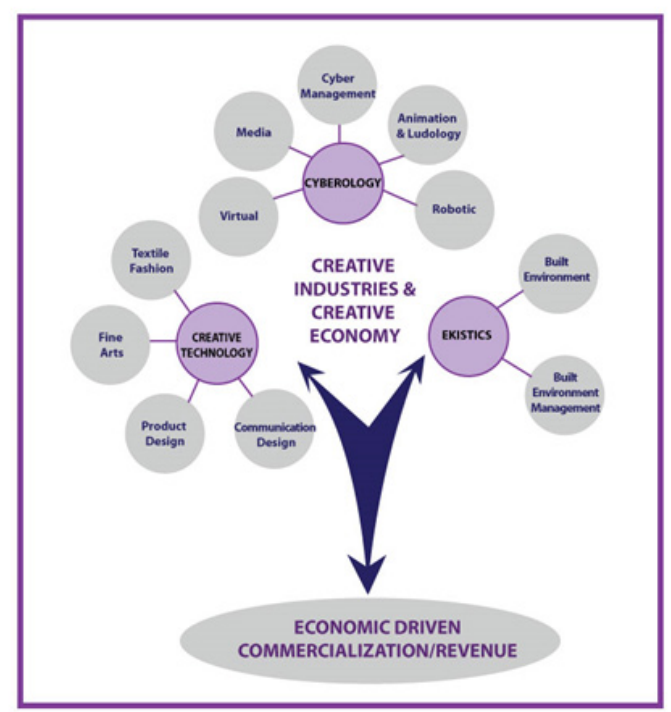

Figure 1: Existing Research Sub-clusters in FTKW 


\subsection{The future FAE}

The future FAE has been planned to start with the offering of three academic programmes as follows:

$\begin{array}{ll}\text { i. } & \text { ljazah Sarjana Muda Sains Senibina } \\ \text { ii. } & \text { ljazah Sarjana Muda Senibina Dalaman } \\ \text { iii. } & \text { ljazah Sarjana Muda Senibina Landskap }\end{array}$

FAE resembles FTKW's aspiration of academic programme development and research agenda. Other academic programmes that will be planned for offer include the following:

$\begin{array}{ll}\text { i. } & \text { Sarjana Muda Sains Ukur Bahan } \\ \text { ii. } & \text { Sarjana Muda Sains Pengurusan Bangunan } \\ \text { iii. } & \text { Sarjana Muda Sains Pengurusan Aset } \\ \text { iv. } & \text { Sarjana Muda Sains Pengurusan Fasiliti } \\ \text { v. } & \text { Sarjana Urban Futures } \\ \text { vi. } & \text { Sarjana Pengurusan Nilai }\end{array}$

The implementation strategy will follow the stages of development, enhancement and excellence as per FTKW's strategic plan.

The article by Buchanan (2012) is probably the right source of reference to give a deliberate attention in designing its architecture-based academic programmes. This can be attributed to the detailed outline of thoughts being presented on how the future architecture education should be designed. The article places great importance on sustainability requirement that should tie all architecture-based academic programmes. FAE is in line with this direction by having sustainability as its emphasis.

Meanwhile, the research agenda of FAE will include sub-clusters that can be summarised as Figure 2 .

The future FAE's research agenda aims at providing the platform for scholarship of teaching at the future faculty. Research input and output will furnish learning and teaching activities with informed development in research and innovation in the niche areas. This will start with two sub-clusters namely Built Environment (BE) and Built Environment Management (BEM).

Built Environment sub-cluster will focus on the built form in creative building industries. It will cover the following areas; architecture, landscape architecture, and interior architecture.

Built Environment Management (BEM) sub-cluster will focus on the management aspects of creative

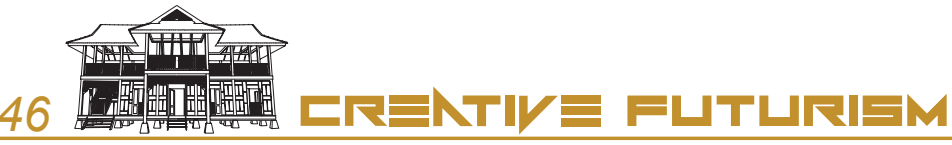


building industries. The emphasis is on multidisciplinary research towards sustainable urban futures. It will cover the following areas: asset management, project planning and management, facilities planning and management, and urban futures. This means postgraduate research will be offered as part of the available academic programmes.

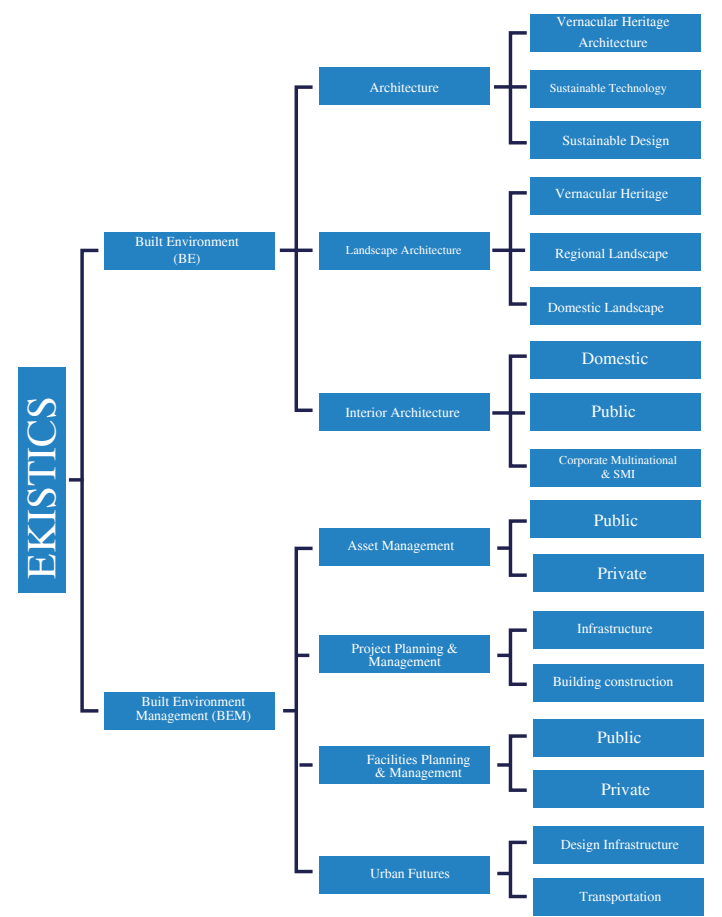

Figure 2: Research sub-clusters at the future FAE

The implementation of FAE's research agenda will be directed towards adapting the concept of mega trends. According to Frosts and Sullivan (2013), mega trends are global, sustained and macroeconomic forces of development that impact business, economy, society, cultures and personal lives thereby defining our future world and its increasing pace of change. Three main trends in urbanisation are Development of Mega Cities, Mega Regions and Mega Corridors. The authors describe that Mega City is a city with minimum population of 10 million for example, Greater London. Meanwhile, Mega Regions are described as cities combining with suburbs to form regions for example, Johannesburg and Pretoria. Lastly, Mega Corridors are major corridors connecting two major cities or mega regions for example, Hong Kong-Shenzhen-Guangzhao in China (with population of 120 million). 


\subsection{Conclusion}

This paper has outlined the basis of formation for the new Faculty of Architecture and Ekistics (FAE). It has highlighted the pursuit of UMK strategic plan by the existing faculty named FTKW. The establishment of the new faculty will be preceded by three academic programmes which are architecture-based. These programmes are to be offered as a head start. Further development will be followed by other academic programmes that relate to human settlements (or Ekistics). FAE will emphasise on a blend of heritage, creative technology and entrepreneurship characteristics as its niche area in delivering knowledge about architecture and ekistics. Two research sub-clusters that will govern the research activities at FAE are Built Environment (BE) and Built Environment Management (BEM). Research activities will be implemented in a multidisciplinary way and will serve as the foundation for the scholarship of teaching at FAE. Ultimately, the final products of FAE should be based on innovative and sustainable design \& management through the adoption of Mega Trends concept.

\section{References}

Frosts and Sullivan (2011). Looking through the crystal ball. Mega trends that will shape the future of the world. http://www.slideshare.net/FrostandSullivan/mega-trends-that-will-shape-the-future-of-the-world (accessed 2 August 2014)

Abu Hassan Hasbullah (2013). "Industri Creative Futures Malaysia: Mengadiluhung Peluang Menjadi Laboritorium Dunia." Jurnal Antarabangsa Creative Futures dan Warisan (TENIAT), Jilid 1, Bil. 1 pg. 1.

Buchanan, P. (2012).The Big Rethink Part 9: Rethinking Architectural Education. http://www.architecturalreview.com/academia/the-big-rethink-part-9-rethinking-architectural-education/8636035.article (accessed 2 August 2014)

http://www.brooklynrail.org/2013/09/criticspage/what-is-architecture-art (accessed 1 September 2013)

http://en.wikipedia.org/wiki/Architecture (accessed 22 July 2014) 